Fish morphology

\title{
THE EFFECT OF SOME PRESERVATIVES AND FREEZING ON CERTAIN BODY DIMENSIONS OF TWO SPECIES \\ OF THE FAMILY MULLIDAE COLLECTED FROM BENGHAZI WATERS, LIBYA \\ WPEYW NIEKTÓRYCH SUBSTANCJI UTRWALAJĄCYCH ORAZ MROŻENIA NA WYBRANE WYMIARY CIALA DWÓCH GATUNKÓW RYB Z RODZINY MULLIDAE POCHODZĄCYCH Z OKOLIC BENGHAZI, LIBIA
}

\author{
${ }^{1}$ School of Biological Sciences, The University of Auckland, New Zealand \\ ${ }^{2}$ Zoology Department, Faculty of Science, Garyounis University, Benghazi, Libya
}

Two preservatives, formalin and alcohol as well as the freezing method were studied to show their effect on three morphological characters of two fish species of the family Mullidae (Mullus barbatus and M. surmuletus) collected from the Libyan coastal waters of the Mediterranean Sea near Benghazi City.

The results showed a variable effect of the preservatives used and the freezing techniques. Shrinkage was the most common effect observed in the preservation tests, although a number of increase cases were obtained as well.

\section{INTRODUCTION}

Ichthyologists have been using various preservation techniques and methods to preserve fish specimens at different stages of their study. Formalin, alcohol and freezing are most commonly used.

Body proportions of fishes exposed to different preservatives show changes, and most authors report a shrinkage in length (Lux 1960; Stobo 1972; Engel 1974; Sayers 1987). The exceptions are Billy (1982) and Al-Hassan and Abdullah (1992) who reported a slight length increase or no shrinkage in the preserved fish, Sarotherodon mosambicus and Barbus luteus respectively. The morphological changes incurred in the preservation process may interfere with the identification and accurate description of fish species. 
The work of Al-Hassan et al. (1999) is considered the only work in this field being done on the fishes of Libya. They report on the effect of preservatives and freezing on two sparid fish species, Diplodus anmularis and Boops boops. No other works are on record about this subject. The present work is a part of a series of studies being conducted on the fish species of Libya to investigate the effect of different preservatives on the morphology of the fish. Thus, the two members of the family Mullidae were chosen for this study, they are the only species of this family that inhabit the Libyan waters (Whitehead et al. 1986).

\section{MATERIAL AND METHODS}

Specimens of Mullus barbatus and M. surmuletus were collected from the coastal waters around Benghazi City, Libya in January 1996. They were divided into seven batches (10 fishes in each) to be used for formalin, alcohol, and freezing experiments. Preservative solutions were prepared as follows: two batches of $5 \%$ formalin, two of $10 \%$ formalin and two of $70 \%$ alcohol.

Then the two batches of each concentration were mixed with tap water and distilled water. The seventh batch was used for freezing experiment for which an ordinary freezer was used. Total length (TL), standard length $(S L)$, and head length $(H L)$ were measured for each fish specimen weekly, during the duration of the experiment that last for ten weeks. No significant morphological changes were observed after the tenth week of experimentation.

\section{RESULTS AND DISCUSSION}

Formalin and alcohol at different concentrations and freezing showed a variable effect on the selected morphological characters chosen of the two mullid fish species (Tab. 1).

The most commonly effect was shrinkage, although the dimension of $\bar{M}$. barbatus increased in 5 cases, while those of $M$. surmuletus - in 4 cases. Furthermore, no effect result was noticed in three cases during the preservation experiments on M. barbatus. No such effect was noticed in $M$. surmuletus. It is evident that M. surmuletus was more prone to shrinkage, while $M$. barbatus was more likely to increase in length.

No effect observed in M. barbatus and the increment of the body dimensions observed in the two fish species is a key conclusiuon of the present study. All other studies have reported some shrinkage associated with preservation. It would appear that the preservation technique used, does not significantly alter fish body proportions in the two mullid fish species. Thus, it may be possible that shrinkage is occurring at a very slow rate and a much longer period of time in formalin and alcohol of different concentrations is required before significant shrinkage can be detected (Figs. 1-4). 
Table 1

Effect of different preservative techniques and methods on morphometric characters of Mullus barbatus and Mullus surmuletus (NE-no effect; d.w.-distilled water; t.w.—tap water; $T L$ — total length; $S L$ —standard length; $H L$ - head length)

\begin{tabular}{|c|c|c|c|c|c|}
\hline \multirow{2}{*}{$\begin{array}{c}\text { Morphological } \\
\text { characters }\end{array}$} & $\begin{array}{c}\text { Preservation } \\
\text { methods } \\
\text { and techniques }\end{array}$ & Effect & $\begin{array}{c}\text { In percentage } \\
\text { points }\end{array}$ & Effect & $\begin{array}{c}\text { In percentage } \\
\text { points }\end{array}$ \\
\cline { 3 - 6 } & $5 \%$ formalin-d.w. & Increase & 0.2747 & Increase & 0.9202 \\
$S L$ & $5 \%$ formalin-d.w. & NE & - & Shrinkage & 0.1504 \\
$H L$ & $5 \%$ formalin-d.w. & Shrinkage & 6.9767 & Shrinkage & 5.2632 \\
$T L$ & $5 \%$ formalin-t.w. & NE & - & Increase & 1.4103 \\
$S L$ & $5 \%$ formalin-t.w. & Increase & 1.6339 & Increase & 0.8130 \\
$H L$ & $5 \%$ formalin-t.w. & Shrinkage & 6.0869 & Shrinkage & 6.7568 \\
$T L$ & $10 \%$ formalin-t.w. & Increase & 0.5911 & Increase & 0.5952 \\
$S L$ & $10 \%$ formalin-t.w. & Increase & 1.2346 & Shrinkage & 0.7519 \\
$H L$ & $10 \%$ formalin-t.w. & Increase & 5.3191 & Shrinkage & 2.8947 \\
$T L$ & $70 \%$ alcohol-d.w. & Shrinkage & 2.3256 & Shrinkage & 4.4444 \\
$S L$ & $70 \%$ alcohol-d.w. & Shrinkage & 2.9940 & Shrinkage & 4.2857 \\
$H L$ & $70 \%$ alcohol-d.w. & Shrinkage & 10.4167 & Shrinkage & 10.0000 \\
$T L$ & $70 \%$ alcohol-t.w. & Shrinkage & 2.0000 & Shrinkage & 3.0726 \\
$S L$ & $70 \%$ alcohol-t.w. & Shrinkage & 5.0955 & Shrinkage & 2.1739 \\
$H L$ & $70 \%$ alcohol-t.w. & Shrinkage & 6.7391 & Shrinkage & 7.6923 \\
$T L$ & Freezing & Shrinkage & 2.3585 & Shrinkage & 4.0119 \\
$S L$ & Freezing & Shrinkage & 1.2789 & Shrinkage & 1.6000 \\
$H L$ & Freezing & Shrinkage & 18.3673 & Shrinkage & 2.8571 \\
\hline
\end{tabular}

The results are consistent with those of Billy (1982) and Al-Hassan and Abdullah (1992). The difference in the effect of preservatives on the different parts of the fish body obtained, might be due to the difference in the chemical composition of each region. Such composition differs from region to region of the fish body respectively to the contraction function.

The greatest length increment was recorded in total length of $M$. barbatus after keeping the fish in 10\% formalin-distilled water (3.6866\% of the live length), while the least increase was also observed in total length of the same species after immersing the fish in $5 \%$ formalin-distilled water $(0.2747 \%$ of the live length). On the other hand, the greatest shrinkage was noticed in the head length of $M$. barbatus after keeping the fish frozen (18.3673\% of the live length), and in M. surmuletus the least shrinkage was observed in standard length of after keeping the fish in 5\% formalin-distilled water $(0.1504 \%$ of the live length). Between the upper and the lower limits, the morphological characters showed some variations under the effect of the preservatives and freezing. 


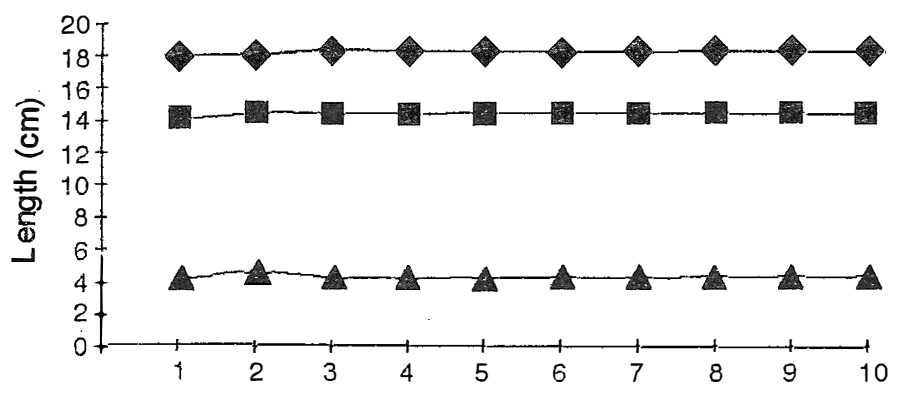

A

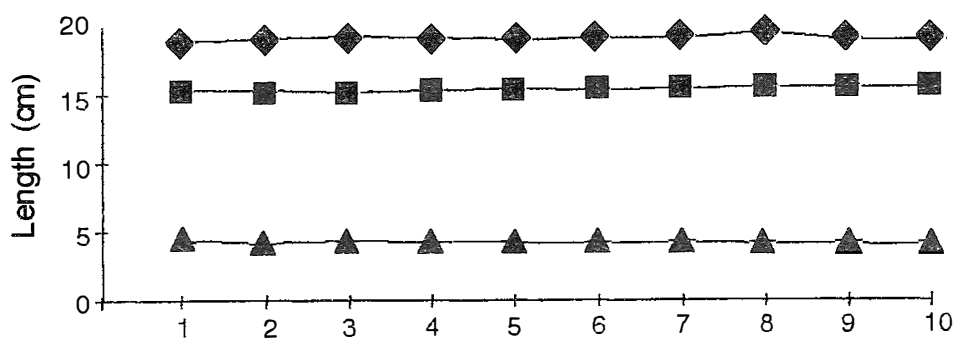

B

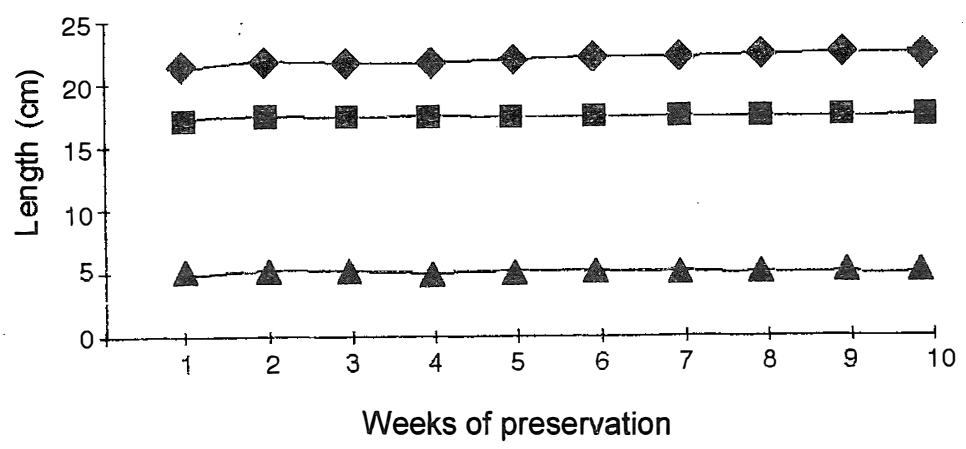

Fig. 1. The relationship between different body dimensions and number of weeks of preservation in Mullus barbatus; A, 5\% formalin in distilled water; B, $5 \%$ formalin in tap water; C, $10 \%$ formalin in distilled water; = head length; = standard length; $=$ total length

Several authors have reported the effect of different preservatives on the morphology of the fish in relation to its size (Stobo 1972). The present result does not agree with their findings. This is also true for the effect of freezing on the size changes of the fish. Sayers (1987) obtained the same results. 


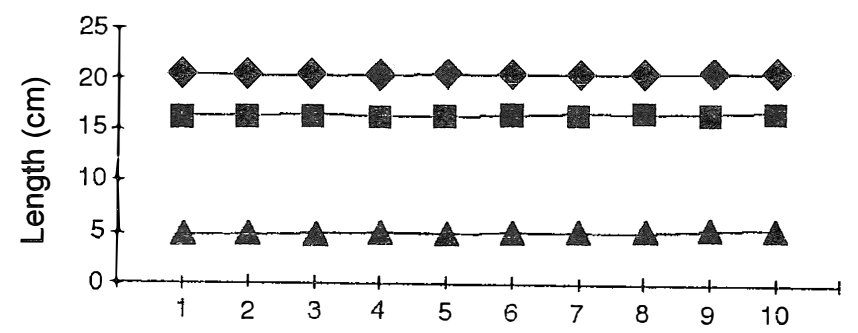

A
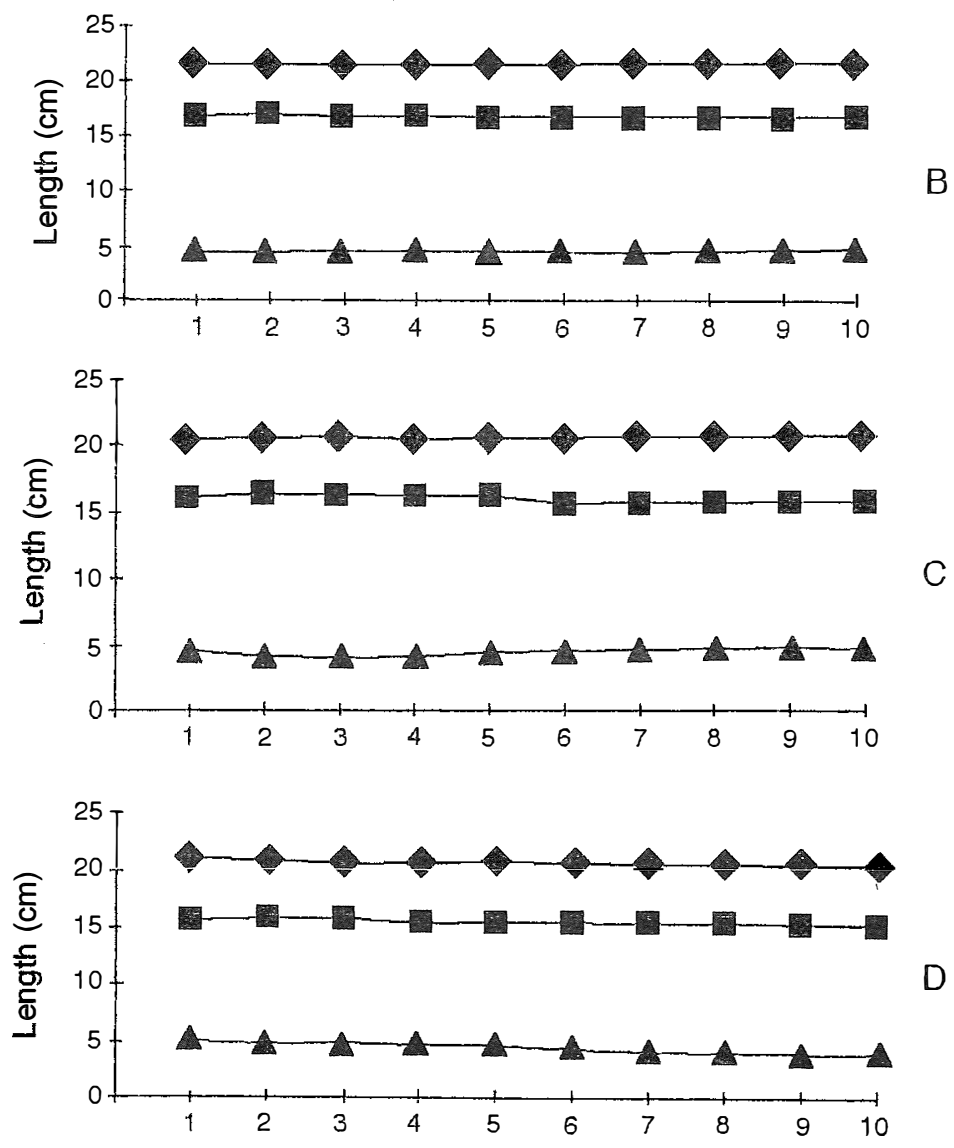

Weeks of preservation

Fig. 2. The relationship between different body dimensions and number of weeks of preservation in Mullus barbatus; A, 10\% formalin in tap water; B, 70\% alcohol in distilled water; C, $70 \%$ alcohol in tap water; D, freezing; $\mathbf{\Delta}=$ head length; $=$ standard length; $=$ total length 

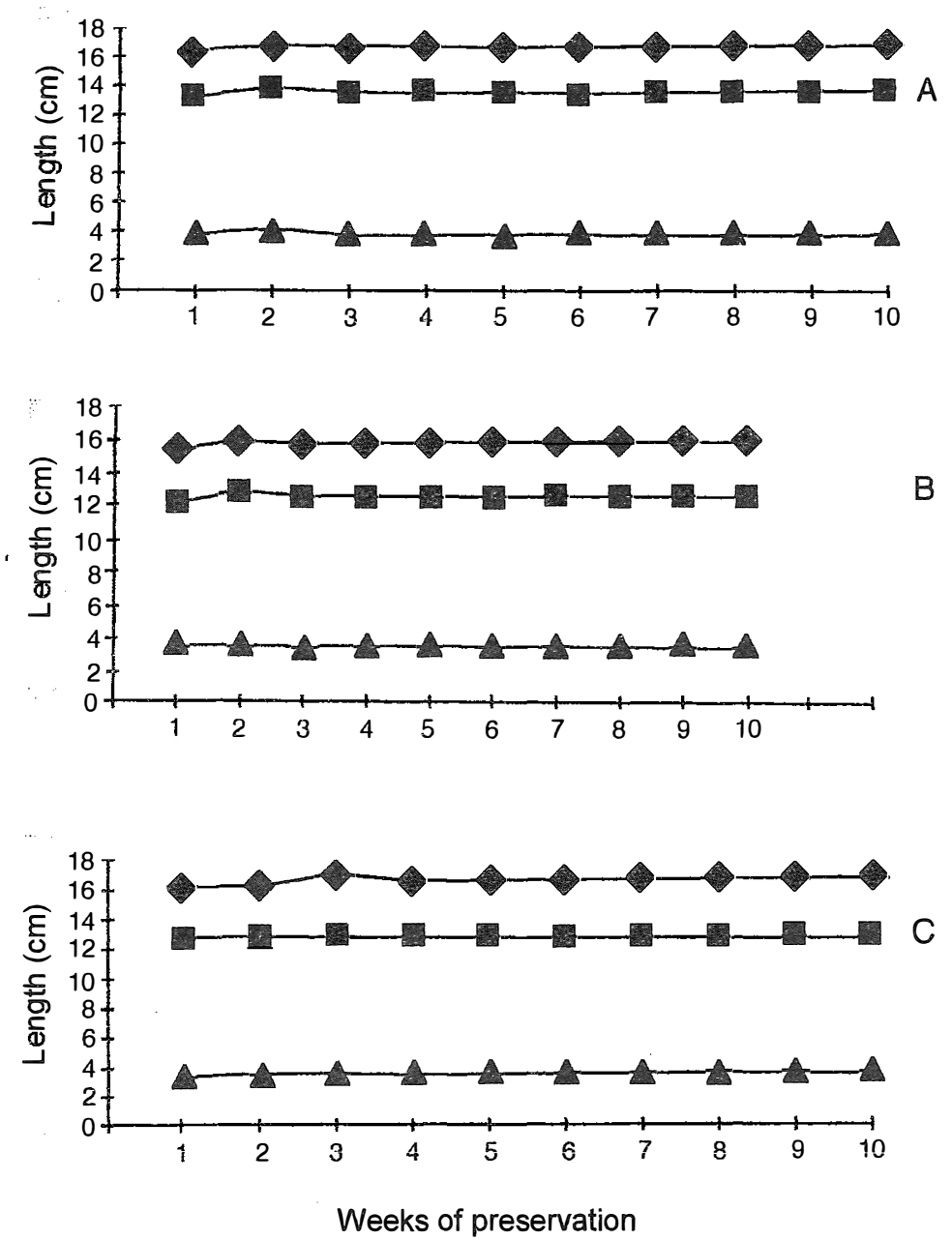

Fig. 3. The relationship between different body dimensions and number of weeks of preservation in Mullus surmuletus; A, 5\% formalin in distilled water; B, 5\% formalin in tap water; C, $10 \%$ formalin in distilled water; $\mathbf{\Delta}=$ head length; $=$ standard length; $\$=$ total length 

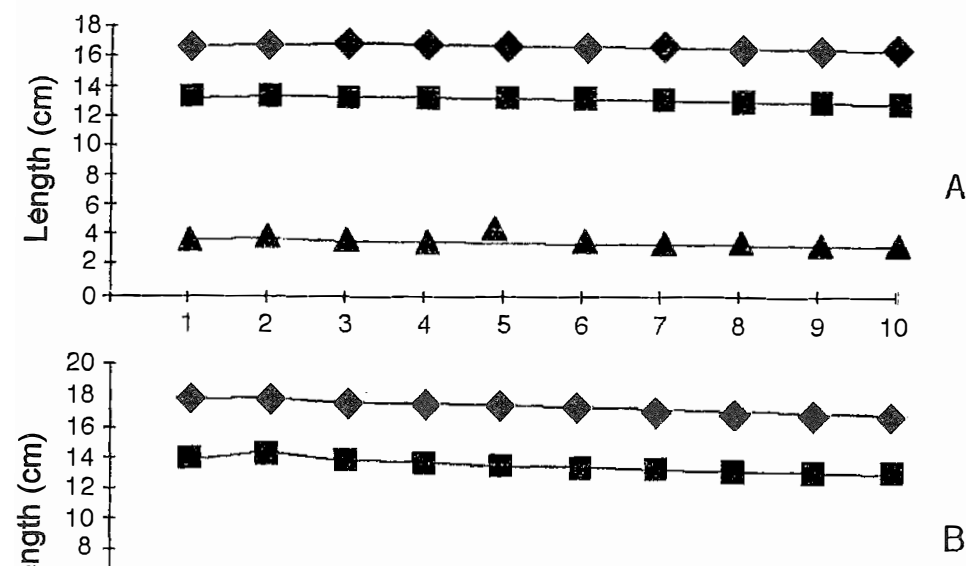

B
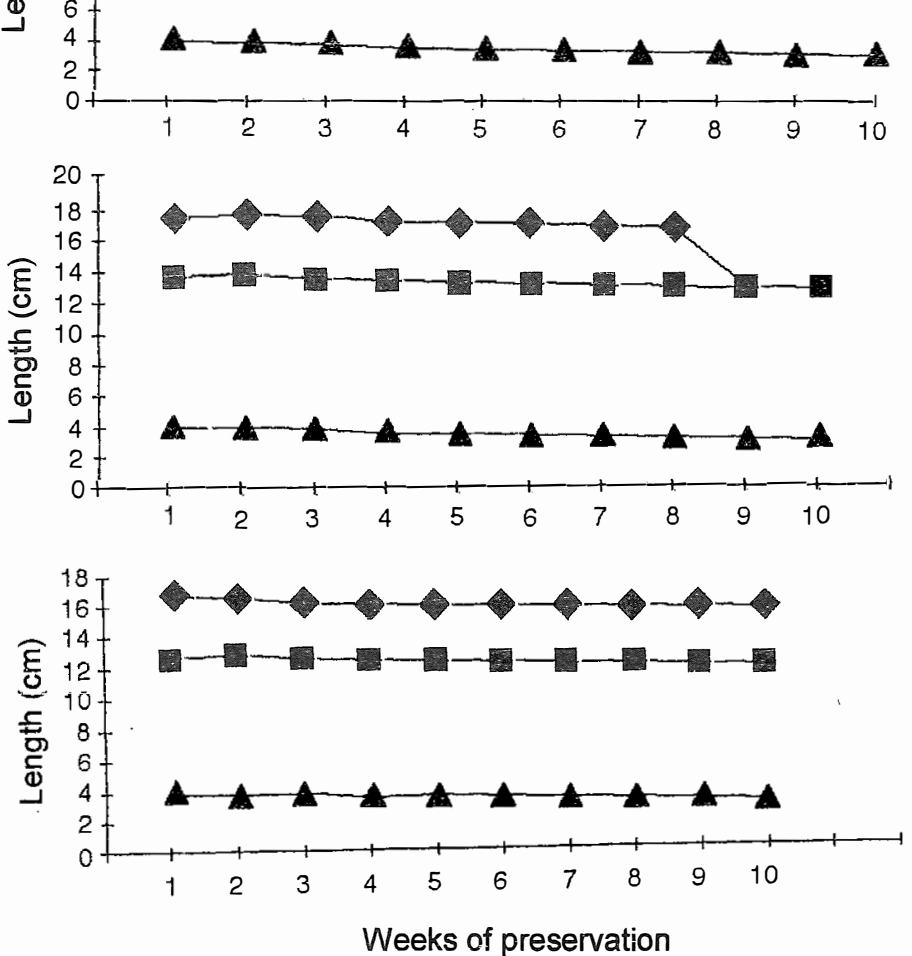

Fig. 4. The relationship between different body dimensions and number of weeks of preservation in Mullus surmuletus; A, 10\% formalin in tap water; B, 70\% alcohól in distilled water; C, $70 \%$ alcohol in tap water; D, freezing; $\Delta=$ head length; $=$ standard length; $\$=$ total length 
Standard correlation factor has been used by several workers to calculate live measurements from preserved fish (Sigler 1949). It is unreliable practice as some authors have suggested (Parker 1963; Stobo 1972; Yeh and Hodson, 1975; Billy 1982). According to Yeh and Hodson (1975) it could be determined separately for each study, but several factors might affect the determination of the correlation factor such as the original state of the fish, time elapsed since preservation, and strength of the preservative medium. Basically, the correlation factors are not reliable outside a specific study, as there is no standardisation in fish preservation technique. Initial shrinkage might occur due to rigor mortis of the fish killed before placing them in the preservatives (Al-Hassan and Abdullah 1992). Thus, differences might appear between the different preservative techniques. In general, standard correlation factor is not applicable, with a possible exception of using it to provide a preliminary rough study specific approximation of the live state.

The differences obtained in the effect of preservatives and freezing on the morphological characters of the two mullid fish species can be explained on the basis that each species has its own characters of tissue water content and its specific ratio of white to red muscles which might interfere with the different preservatives (Leslie and Moore 1986 ). Al-Hassan and Abdullah (1992) and Al-Hassan et al. (1993) reached same results.

\section{CONCLUSIONS}

The different concentrations of formalin and alcohol in addition to freezing showed a variable effect on morphological characters of the fish species $M$. barbatus and $M$. surmuletus. In general fishes appeared to get shrinked after a certain period of preservation time. To a lesser extent, other effects such as an increase in body proportions and no effect cases were also evident.

\section{REFERENCES}

Al-Hassan L.A.J., J.N. Abdullah, 1992: The effect of formalin and freezing on Some body proportions of Barbus luteus. Pakistan J. Zool., 24, 4: 353-354.

Al-Hassan L.A.J., S.D. Saleem, M.K. Melkonian, 1993: Effect of freezing, formalin, and alcohol on certain body proportions of the clupeid fish, Nematalosa nasus, collected from the Khor Al-Zubair area (North-West region of the Arabian Gulf). Acta Hydrobiol., 35, 2: 179-183.

Al-Hassan L.A.J., J.A. Bujawari, O.A. El-Silini, 1999: Additional report on the effect of preservatives and freezing on the morphological characters of four sparid fish species collected from Benghazi, Libya. J. Anim. Morph. Physiol., 46. (In press).

Billy A.J., 1982: The effect of formalin and isopropyl alcohol on length and weight measurements of Sarotherodon mossambicus Trewaves. J. Fish Biol., 21: 107-112. 
Engel S., 1974: Effects of formalin and freezing on lengths, weight and condition factor of cisco and yellow perch. Trans. Amer. Fish. Soc., 1: 136-138.

Leslie J.K., J.E. Moore, 1986: Changes in lengths of fixed and preserve young freahwater fish. Can. J. Fish. Aquat. Sci., 43: 1079-1081.

Lux F.E., 1960: Length shrinkage of yellow tail flounder between live and landed condition. Trans. Amer. Fish. Soc., 89: 373-374.

Parker R.E., 1963: Effects of formalin on length and weight of fishes. J. Fish. Bd. Can., 20: 14411455.

Sayers R.E., 1987: Effects of freezing in and out of water on length and weight of Lake Michigan Bloaters. Amer. Fish. Manag., 7: 299-301.

Sigler W.F., 1949: Life history of the white bass in Storm Lake, Iowa. Iowa State Coll. J. Sci., 23, 4: 311-316.

Stobo W.T., 1972: Effects of formalin on the length and weight of yellow perch. Trans. Amer. Fish. Soc., 101: 362-364.

Whitehead P.J.P., M.L. Bauchot, J.C. Hureau, J. Nielson, E. Tortones, 1986: Fishes of the North-East Atlantic and the Mediterranean. UNESCO, vol. 1-3.

Yeh C.F., R.G. Hodson, 1975: Effects of formalin on length and weight of blue-gill and white crappie from Lake Nasworthy. Texas West Nat., 20: 315-322.

\author{
L.A.J. AL.-HASSAN, J.A BUJAWARI, O.A. EL-SILINI \\ WPŁYW NIEKTÓRYCH SUBSTANCJI UTRWALAJACYCYCH ORAZ MROŻENIA \\ NA WYBRANE WYMIARY CIAŁA DWÓCH GATUNKÓW RYB Z RODZINY \\ MULLIDAE POCHODZĄCYCH Z OKOLIC BENGHAZI, LIBIAA
}

\title{
STRESZCZENIE
}

Analizowano wplyw substancji utrwalających - formaliny i alkoholu oraz mrożenia na trzy cechy morfologiczne dwóch gatunków ryb z rodziny Mullidae (Mullus barbatus i Mullus surmu letus) złowionych w przybrzeżnych wodach Libii w pobliżu miasta Benghazi.

Badania wykazały, że obie substancje utrwalające i mrożenie mają zróżnicowany wplyw na analizowane cechy ryb. Najczęściej obserwowaną zmianą było kurczenie się materiału badawczego. Niektóre jednak ryby wykazywały nieznaczny wzrost długości ciała pod wpływem zastosowanych środków konserwujących.

Author's address:

L.A.J. Al-Hassan

School of Biological Sciences

The University of Auckland, New Zealand

Private Bag 92019 